\title{
The Utilization Of Culture Map Board Media To Improve Teachers 'Skills In Elementary School
}

\author{
Mu'arifatun Ni'mah Arindita \\ Jurusan Pendidikan Sekolah Dasar, Universitas Muria Kudus, Kudus, Indonesia \\ Email: arinditaarindita4@gmail.com
}

Irfai Fathurohman

Dosen Pendidikan Bahasa dan Sastra Indonesia, Universitas Muria Kudus, Kudus, Indonesia Email: irfai.fathurohman@umk.ac.id

Deka Setiawan

Dosen Pendidikan Bahasa dan Sastra Indonesia, Universitas Muria Kudus, Kudus, Indonesia Email:deka.setiawan@umk.ac.id

\section{A R T I C L E I N F O \\ Article history: \\ 1 Mei 2020 Received in revised form \\ 11 Juni 2020 \\ Accepted 10 Juli 2020 \\ Available online 25 Agustus 2020

Kata Kunci:
papan peta budaya,
keterampilan guru

\section{Keywords:}

cultural map board, teachers' skills

\begin{abstract}
A B S T R A K
Kurangnya keterampilan guru dalam mengajar dan kurangnya penggunaan media pembelajaran, mengakibatkan proses pembelajaran tidak berjalan dengan baik. Penelitian ini bertujuan untuk menganalisis peningkatan keterampilan guru dengan pemanfaatan media papan peta budaya. Jenis penelitian ini adalah Penelitian Tindakan Kelas. Penelitian ini berlangsung selama dua siklus, setiap siklus terdiri dari empat tahapan yakni perencanaan, pelaksanaan, pengamatan dan refleksi. Teknik pengumpulan data terdiri dari wawancara dengan menggunakan pedoman wawancara, observasi dengan menggunakan lembar observasi keterampilan guru dan dokumentasi. Teknik analisis data yang digunakan merupakan analisis data kualitatif dan kuantitatif. Hasil keterampilan guru berbantuan media papan peta budaya memperoleh rata-rata presentase siklus I sebesar 70 $\%$ dan meningkat di siklus II presentase $80 \%$ dengan kategori baik. Berdasarkan hasil penelitian ini dapat disimpulkan bahwa dalam menggunaan media papan peta budaya dapat meningkatkan keterampilan guru di SD.
\end{abstract}

\begin{abstract}
A B S T R A C T
Lack of teacher skills in teaching and the lack of the use of instructional media lead to ineffective learning process. This study aims to improve the skills of teachers assisted by cultural map board media. This research was carried out by classroom action research. This research lasted for two cycles, which each cycle consists of four stages, including planning, implementing, observing and reflecting. Data collection techniques consisted of interviews using interview guidelines, as well as observation using teacher skills observation sheets and documentation. The data analysis technique used is qualitative and quantitative data. The results shows that the skills of the teacher assisted by the cultural map board media obtained an average in cycle I in percentage of $70 \%$ and increases in cycles II by $80 \%$ with good category. Based on the result of this study, it can be concluded that using the cultural map board media can improve the teachers' skills in Elementary School.
\end{abstract}

\section{Introduction}

The current 2013 curriculum emphasizes the learning process. The learning process assessed in the 2013 curriculum is more focused on spiritual or affective aspects, while cognitive and psychomotoric aspects become competence after affective aspects (Mulyadin, 2016; Yama \& Setiyani, 2016). The 2013 curriculum also anticipates the development and science of the 21st century where there has been a shift in the learning model, teachers play an active role in the implementation of the learning process that applies the 2013 curriculum. The teacher's role in the learning process is supported by the skills or competencies possessed by the teacher themselves. Some of the competencies that must be possessed by a teacher are pedagogical competence, personal competence, professional competence, and social competence. These four competencies must be used by teachers to support the achievement of the learning process in the classroom (Nuroidah \& Anwar, 2015; Umar, 2019).

Teacher skills are general characteristics of a person related to knowledge and skills that are manifested through action (Sophuan, 2018; Suparno, 2013). Basic teaching skills are basically forms of fundamental and specific behavior that a teacher must have as an initial capital to carry out applicative learning tasks. However, not all teachers have good basic teaching skills. 
Based on the results of the pre-cycle, interviews and observations, it shows that there are problems in grade IV SDN Pohgading which are still low. From the results of observations, it shows that the teacher still uses the lecture method in teaching so that the students feel bored. However, the limitations of the teacher in the use of learning media are less varied, impacting on the learning delivered by the teacher is less optimal. From the precycle results through the observation instrument teacher skills that have been implemented at SDN Pohgading get a percentage of $44 \%$ (not good). This is because the teachers have not used innovative and varied learning models and they rarely use supporting learning media. Therefore, an effort is needed to improve teacher skills in teaching by using learning media. One of the main tasks of the teacher in designing meaningful learning for students is to create learning media that can attract students' interest in learning (Aribowo, 2018; Kusumaningtyas et al., 2020).

Learning media is a source of information that contains learning material and learning evaluation, as a source of information learning media can be used to add new experiences and create meaningful learning for students (Rochimatun, 2016; Yektyastuti \& Ikhsan, 2016). Learning media can help to improve understanding, so that the students are able to think actively and creatively, present data attractively, and clarify the delivery of teaching material (Sa'adah et al., 2017; Siswanah, 2013). Learning media is defined as a communication component that functions as an intermediary to convey messages from sender to recipient, making learning media can improve teacher skills and provide stimulation for students to increase their interest in learning (Ernawati, 2014; Yusantika et al., 2018).

The selection of appropriate learning media given to students in the learning process affects students' interest in learning (Laily et al., 2019; Murningsih, 2014). The use of learning media can attract students' attention to learn, if the teacher is able to create a pleasant learning atmosphere so that students feel happy following the learning process. Therefore learning media is very important not only to increase student's interest in learning but also improve teacher skills in creating a creative and innovative learning media (Alannasir, 2018; Siswanah, 2013). To overcome the problems, one of the solutions given is to use cultural map board media.

In this study, the developed media board was focused on making material maps about culture contained in the beautiful theme of diversity in my country in Sub-themes 1 and 2. This cultural map board media was developed by researchers from several combined media and reading information from each province. This media includes pictures, maps, traditional houses, traditional clothes, and grouping of various tribes. Through the use of this cultural map board media, students can learn while playing. The cultural map board media used, can play a role as a means of developing student activeness in participating in learning, while the teachers can develop their skills because the material provided is in the form of a mind map that will attract student learning interest. Besides, the use of this cultural map board media serves to overcome the large amount of material used given in insufficient time (Indawati \& Alfiana, 2017; Triastuti et al., 2017).

Previous researches that are relevant to this research include: (1) research conducted by (Nikmatillah, 2018) which obtained the results of the study that the use of cross-board media had a significant increase in student learning outcomes and student responses to science learning in the material of cross-breeding of living things. (2) research by (Triastuti et al., 2017) which obtained the results that panjat pinang board game media for thematic learning of the circulatory system of humans and animals in grade $\mathrm{V}$ elementary schools was included in the very valid, practical, interesting, and effective category to use. (3) research conducted by (Indawati \& Alfiana, 2017) which obtained the results that the use of map board learning media can increase social studies students' achievement. Based on these three studies, the novelty of this study is the use of cultural map board media to improve teacher skills in elementary schools. The purpose of this study is to analyze the improvement of teacher skills with the use of cultural map board media.

\section{Method}

This research is a Classroom Action Research. The implementation of this classroom action research was carried out on grade IV SDN Pohgading with 19 research subjects. This research lasted for two cycles consisting of four stages of planning, implementing, observing and reflecting.

This research was conducted for two cycles using a design from Kemmis and Mc. Traggart (Arikunto \& Suharsimi, 2012). This study is focused on improving teacher skills by utilizing cultural map board media on the beautiful theme of diversity in my country in Sub-themes 1 and 2. The independent variable in this study is the cultural map board media and the dependent variable in this study is teacher skills.

The instrument in this study was an interview to obtain information about learning problems, and observation to measure teacher skills during the learning process and learning documentation.

The data analysis technique in this research is in the form of qualitative and quantitative data analysis. Qualitative statistical analysis was used to analyze data from the average percentage results in cycle I and cycle II. Meanwhile, qualitative analysis is used to process data in the form of suggestions given by grade IV teachers. 


\section{Result and Discussion}

Teacher skills in teaching are one type of skills that must be mastered by teachers such as managing the learning process well, so that learning can run effectively and efficiently (Yama \& Setiyani, 2016). This classroom action research consisted of pre-class phase, cycle I and cycle II to measure the ability of teachers' skills in teaching on the content of PPKn and Indonesian for grade IV SDN Pohgading assisted by cultural map board media with 19 students as the subject. In practice, students pay attention to the subject matter delivered by the teacher, students form heterogeneous groups consisting of 4-5 members. After students receive assignments from the teacher and discuss them, they play a cultural map board media game by taking turns and taking question cards according to the directions given by the teacher. Students who successfully answer get points from the teacher. Then the points are accumulated, the winner is the student with the highest points and gets the award.

The observation stage was assisted by peers by observing the teacher's skills in teaching assisted by the media of a cultural map board during the learning process. The following shows the results of the teacher's skills in teaching. Data from the observation of teacher skills in cycle I can be seen in Figure 1.

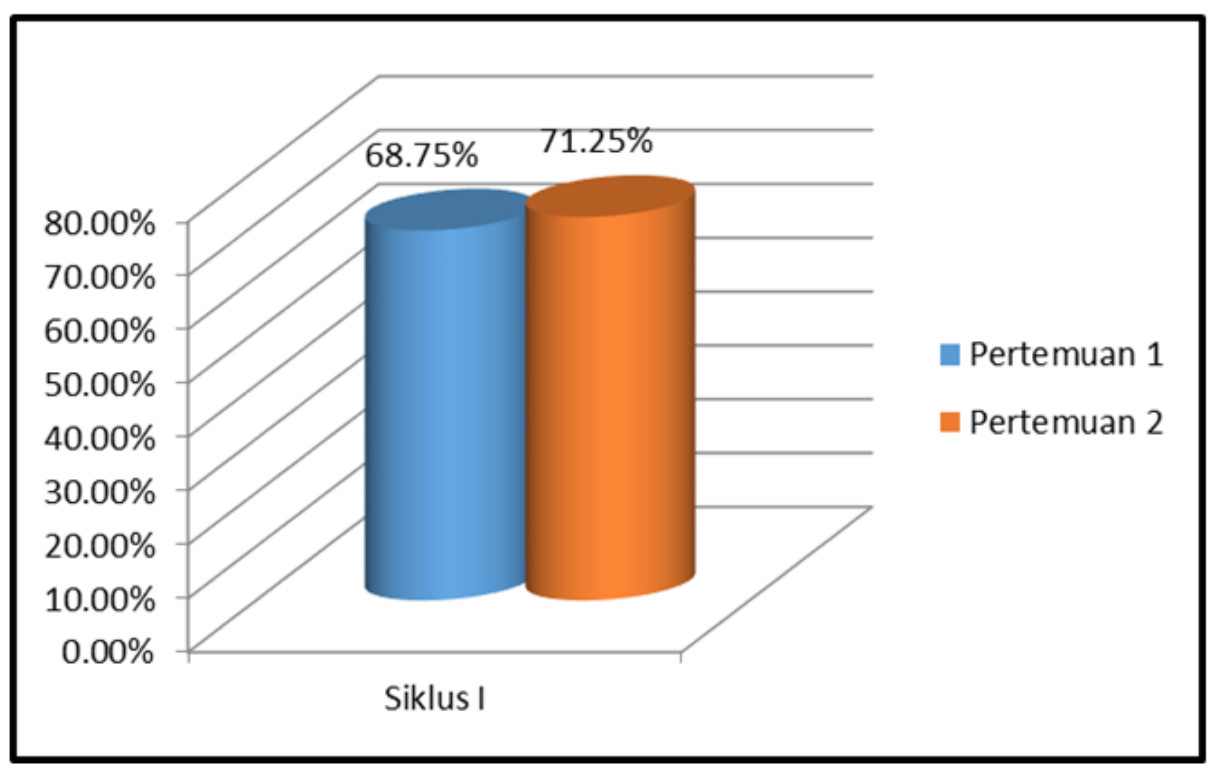

Figure 1. Data from the observation of teacher skills in cycle I

The implementation of the teacher's skills in cycle I by using the cultural map board media obtained data at meeting 1 by percentage of $68.75 \%$ and meeting 2 of $71.25 \%$ with an average percentage of cycle I is $70 \%$. Teacher skills have not reached the indicator set at $75 \%$. The research still needs to carry out into cycle II because it has not reached the success indicators and there are still many problems that need to be fixed. Problems that need to be fixed in cycle II is the the lack of teacher skills in implementing rock-based learning with cultural map board media. It is planned that improvements to the learning process will be carried out in cycle II, includes (1) the teacher will always provide feedback for students (2) the teacher will invite students to use the media in finding material concepts (3) the teacher will improve class mastery so that the class is always conditional during the learning process (4) the delivery of the material will be carried out coherently and clearly.

The results of the observation of teacher skills in cycle II by using the cultural map board media obtained data at the first meeting by percentage of $76.25 \%$ and the second meeting of $83.75 \%$ with an average percentage of the second cycle is $80 \%$. Teacher skills have reached the indicator set at $75 \%$. Researchers do not need to proceed to the next cycle because they have reached the specified success indicators, but there are some inputs from grade IV teachers at SDN Pohgading that need to be improved as well as teaching guidelines. Following are the results of improving the skills of the teacher in the second cycle that can be seen at the diagram below. Data from the observation of the second cycle of teacher skills can be seen in Figure 2. 


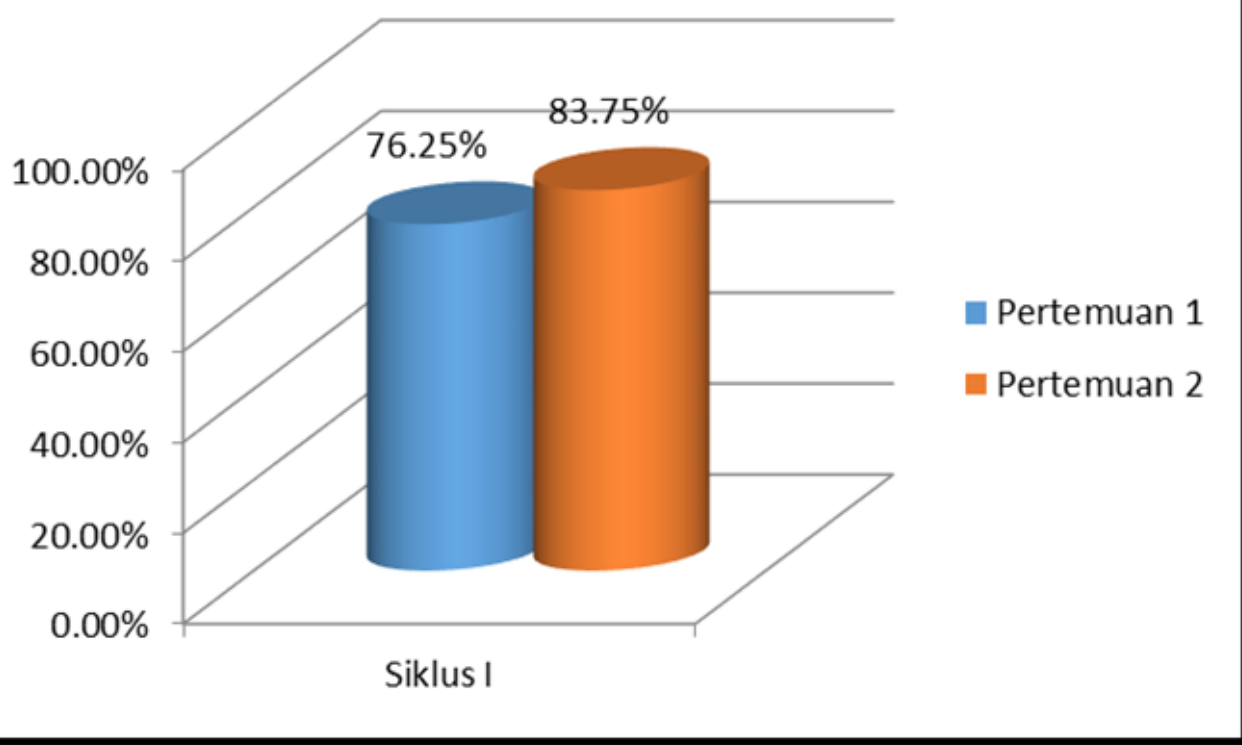

Figure 2. Data from the observation of teacher skills in cycle II

There is an increase in the percentage of teacher skills in the implementation of learning. It is due to the learning media is defined as a communication component that functions as an intermediary to convey messages from sender to the recipient. Making learning media can improve teacher skills and provide stimulation for students to increase student interest in learning (Ernawati, 2014; Yusantika et al., 2018). So that learning media is very important in addition to increase student interest in learning. It can also improve teacher skills in creating creative and innovative learning media.

Success in the learning process cannot be separated from the use of media which is developed in accordance with student characteristics and learning objectives such as conformity with learning materials, core competencies, and basic competencies contained in these materials (Nomleni \& Manu, 2018; Ulfah \& Soenarto, 2017). Teachers should develop media in accordance with several things that must be taken into account, therefore competence is needed to develop learning media and manage classes in order to achieve the desired learning objectives. This has been conducted research (Yama \& Setiyani, 2016) which results showed that there was an effect of teacher training, teacher competence, and the use of infrastructure on the readiness of management business study program teachers to achieve learning objectives in implementing the 2013 curriculum at SMK N 1 Purbalingga in the 2014/2015 academic year.

The use of cultural map board media can help teachers to clarify the presented material. The cultural map board media is a combination of media and information reading from each province. This media includes pictures, maps, traditional houses, traditional clothes, and grouping from various tribes. Through the use of this cultural map board media, students can learn while playing. This research is supported by (Bahtiar, 2019) which obtained the results that the use of time board media in learning time calculations for third grade students of SDN Petemon XIII / 361 Surabaya in the 2017-2018 academic year was included in the effective category.

Cultural map board media can be used as a means in developing student activeness in learning. The advantage of using cultural board media is that it can be used or utilized to overcome the large number of materials. This media can also train teachers to improve teacher skills in teaching (Indawati \& Alfiana, 2017; Khamadi \& Senoprabowo, 2016; Laily et al., 2019).

Previous researches that are relevant to this research includes: (1) research conducted by (Nikmatillah, 2018) which obtained the results that the use of cross-board media had a significant increase in student learning outcomes and student responses to science learning in the material of cross-breeding of living things. (2) research by (Triastuti et al., 2017) which obtained the results of the research that panjat pinang board game media for thematic learning of the circulatory system of humans and animals in grade V elementary schools were included in the very valid, practical, interesting, and effective category to use. (3) research conducted by (Indawati \& Alfiana, 2017) which obtained the results that the use of map board learning media can increase student social studies achievement. Based on these three studies, and the results of data analysis, it was found that there was an increase in the skills of teachers in teaching by using the media of a cultural map board on the theme of the beauty 
of diversity in my country, grade IV SDN Pohgading in cycle I obtained an average percentage of $70 \%$ and increased in cycle II with the average percentage is $80 \%$ and the success indicator has reached $75 \%$.

\section{Conclusion}

Based on the results of the research, it was concluded that there was an increase in the skills of teachers in teaching using cultural map board media on the theme of the beauty of diversity in my country, grade IV SDN Pohgading. In cycle I, it is obtained an average percentage of 70\%, and increased in cycle II by $80 \%$ and has achieved a success indicator of $75 \%$. The teacher should implement the use of cultural map board media in the learning process to improve the skills possessed by the teacher to develop media and use interesting and innovative learning models and train the ability to manage the class well in order to achieve the desired learning goals.

\section{References}

Alannasir, W. (2018). Pengaruh Penggunaan Media Animasi Dalam Pembelajaran IPS Terhadap Motivasi Belajar Siswa Kelas Iv Sd Negeri Mannuruki. Journal of EST, 2(2), 81-90.

Aribowo, E. K. (2018). Digitalisasi Aksara Jawa Dan Pemanfaatannya Sebagai Media Pembelajaran Bagi Musyawarah Guru Mata Pelajaran Bahasa Jawa Smp Kabupaten Klaten. Warta LPM, 21(2), 59-70. https://doi.org/10.23917/warta.v21i2.5620

Arikunto, \& Suharsimi. (2012). Penelitian Tindakan Kelas. Jakarta: Bumi Aksara.

Bahtiar, R. S. (2019). Efektivitas Penggunaan Media Papan Waktu Pada Pembelajaran Penghitungan Waktu Bagi Siswa Kelas Iii Sekolah Dasar. Jurnal Bidang Pendidikan Dasar, 3(1), 14-23. https://doi.org/10.21067/jbpd.v3i1.2857

Ernawati, E. (2014). Pemanfaatan Media Pembelajaran Audio Visual Untuk Meningkatkan Hasil Belajar PAI Pada Siswa Kelas V SDN Kalianget Timur X. PEDAGOGIA: Jurnal Pendidikan, 3(2), 81. https://doi.org/10.21070/pedagogia.v3i2.59

Indawati, N., \& Alfiana, R. (2017). Peningkatan Prestasi Belajar IPS Melalui Media Papan. Jurnal Bidang Pendidikan Dasar (JBPD), 1(2), 37-43.

Khamadi, \& Senoprabowo, A. (2016). Model Adaptasi Permainan Papan Tradisional Macanan. Andharupa, 02(02), 65-78. https://doi.org/https://doi.org/10.33633/andharupa.v2i02.1219

Kusumaningtyas, R., Sholehah, I. M., \& Kholifah, N. (2020). Peningkatan Kualitas Pembelajaran Guru Melalui Model dan Media Pembelajaran bagi Generasi Z. Warta LPM, 23(1), 54-62. https://doi.org/10.23917/warta.v23i1.9106

Laily, A., Jalal, F., \& Karnadi, K. (2019). Peningkatan Kemampuan Konsep Matematika Awal Anak Usia 4-5 Tahun melalui Media Papan Semat. Jurnal Obsesi : Jurnal Pendidikan Anak Usia Dini, 3(2), 396-403. https://doi.org/10.31004/obsesi.v3i2.214

Mulyadin. (2016). Implementasi Kebijakan Pembelajaran Tematik Terpadu Kurikulum 2013 Di SDN Kauman 1 Malang Dan SD Muhammadiyah 1 Malang. Jurnal Edutama, 3(2), 31-48. https://doi.org/http://dx.doi.org/10.30734/jpe.v3i2.35

Murningsih, E. S. (2014). Meningkatkan Hasil Belajar Siswa Melalui Media Pembelajaran Multimedia Interaktif. $\begin{array}{lll}\text { Jurnal Madaniah, 214-229. } & \text { 4(2), }\end{array}$ https://www.journal.stitpemalang.ac.id/index.php/madaniyah/article/view/42

Nikmatillah, N. (2018). Penggunaan Media Papan Persilangan dapat Meningkatkan Hasil Belajar IPA Materi Perkawinan Silang Mahluk Hidup untuk Siswa Kelas IX C SMP Negeri 7 Malang Tahun 2015/2016. Jurnal Bidang Pendidikan Dasar, 2(1), 1-8. https://doi.org/10.21067/jbpd.v2i1.2187

Nomleni, F. T., \& Manu, T. S. N. (2018). Pengembangan Media Audio Visual dan Alat Peraga dalam Meningkatkan Pemahaman Konsep dan Pemecahan Masalah. Scholaria: Jurnal Pendidikan Dan Kebudayaan, 8(3), 219-230. https://doi.org/10.24246/j.js.2018.v8.i3.p219-230

Nuroidah, I., \& Anwar, M. A. (2015). Implementasi Dan Problematika Kurikulum 2013 Pada Mata Peleajaran Pendidikan Agama Islam Jurusan Ilmu Keagamaan Di Man Rejoso Jombang. DIRASAT, Jurnal Manajemen \& Pendidikan Islam, 1(1), 1-28.

Rochimatun, S. (2016). Optimalisasi Penerapan Metode Diskusi Kelompok Untuk Meningkatkan Hasil Belajar 
Ekonomi Dengan Materi Pokok Ekonomi dan Sistem Ekonomi Pada Siswa Kelas X.3 Semester Satu SMA Negeri 3 Sukoharjo Tahun Pelajaran 2014/2015. Jurnal Pendidikan Ilmu Sosial, 26(2), 12-23. https://doi.org/10.21831/pg.v11i2.10659

Sa'adah, I., Prmono, S. E., \& Suharso, R. (2017). Pengembangan Media Video Motion Graphic Sejarah Pemerintahan Herman Willem Daendels (1808-1811) dalam Pembelajaran Sejarah Indonesia Untuk Meningkatkan Minat Belajar Siswa Untuk SMA. Indonesian Journal of History Education, 5(1), $25-31$.

Siswanah, E. (2013). Penggunaan Media Animasi Dalam Mahasiswa Tadris Matematika Iain. Jurnal Phenomenon, $3(2), 5-17$.

Sophuan. (2018). Peningkatkan Keterampilan Mengajar Guru SMP Mata Pelajaran IPA Dalam Menerapkan Pendekatan Saintifik. Tadrib, 4(2), 335-355. https://doi.org/https://doi.org/10.19109/tadrib.v4i2.2860

Suparno, A. (2013). Kontribusi Pelatihan Guru, Iklim Organisasi Dan Persepsi Guru Tentang Keterampilan Manajerial Kepala Sekolah Terhadap Keterampilan Guru Dalam Pembelajaran Smkn Kota Semarang. Jurnal VARIDIKA, 25(1), 53-65. https://doi.org/10.23917/varidika.v25i1.719

Triastuti, D., Akbar, S., \& Irawan, E. B. (2017). Pengembangan Media Papan Permainan Panjat Pinang. Jurnal Pendidikan, 2(10), 1344-1350. https://doi.org/2502-471X

Ulfah, D. M., \& Soenarto, S. (2017). Pengaruh penggunaan media video dan gambar terhadap keterampilan menulis kelas V. Jurnal Prima Edukasia, 5(1), 22-34. https://doi.org/10.21831/jpe.v5i1.7693

Umar, J. (2019). Kompetensi Profesional Guru Qur'an Hadits Di MTsN 8 Pidie. Jurnal MUDARRISUNA, 9(2), 437-453. https://doi.org/10.22373/jm.v9i2.4126

Yama, S. F., \& Setiyani, R. (2016). Pengaruh Pelatihan Guru, Kompetensi Guru Dan Pemanfaatan Sarana Prasarana Terhadap Kesiapan Guru Prodi Bisnis Manajemen Dalam Implementasi Kurikulum 2013. Economic Education Analysis Journal, 5(1), 85-99.

Yektyastuti, R., \& Ikhsan, J. (2016). Pengembangan Media Pembelajaran Berbasis Android pada Materi Kelarutan untuk Meningkatkan Performa Akademik Peserta Didik SMA Developing Android-Based Instructional Media of Solubility to Improve Academic Performance of High School Students. Jurnal Inovasi Pendidikan IPA, 2(1), 88-99. https://doi.org/10.21831/jipi.v2i1.10289

Yusantika, F. D., Suyitno, I., \& Furaidah. (2018). Pengaruh Media Audio dan Audio Visual terhadap Kemampuan Menyimak Siswa Kelas IV. Jurnal Pendidikan, 3(2), 251-258. http://journal.um.ac.id/index.php/jptpp/ EISSN: 2502-471X DOAJ-SHERPA/RoMEO-Google Scholar-IPI\%0AJurnal 